\title{
KETERBACAAN TEKS NON-SASTRA PADA BUKU BAHASA INDONESIA KELAS X KURIKULUM 2013 DENGAN FORMULA FRY
}

\author{
Masyra'atul Zaim \\ Program Studi Pendidikan Bahasa dan Sastra Indonesia, Fakultas Keguruan dan Ilmu \\ Pendidikan, Universitas Muhammadiyah Surabaya \\ masyzey@gmail.com
}

\begin{abstract}
ABSTRAK
Keterbacaan berkaitan dengan keseluruhan unsur yang ada dalam teks atau materi bacaan. Materi bacaan dalam suatu buku ajar harus selalu diperhatikan karena hal tersebut berpengaruh terhadap tingkat pemahaman peserta didik. Penelitian ini bertujuan untuk mengetahui keterbacaan teks yang terdapat pada buku ajar Cerdas Berbahasa Indonesia untuk SMA/MA Kelas X (Kurikulum 2013) terbitan Erlangga, dengan fokus penelitian pada wacana non-sastra. Ada lima sampel wacana yang dihitung keterbacaannya menggunakan Grafik Formula Fry. 2 sampel diantaranya memiliki wacana yang sesuai dengan tingkatan kelas 5,6,7. 2 yang lainnya memiliki wacana yang sesuai dengan tingkatan kelas 7,8,9. Dan satu sampel yang benar-benar memiliki wacana sesuai dengan tingkatan kelas 10, 11, 12 SMA/MA. Dari hasil rata-rata perhitungan sampel wacana tersebut, buku ini masih memiliki keterbacaan yang tinggi untuk kelas setingkat SMA/MA. Sehingga dibutuhkan peran pengajar untuk selalu meneliti bahan ajar yang digunakan terutama teks bacaan agar sesuai dengan tingkatan kelas siswa.
\end{abstract}

Kata kunci: keterbacaan, buku bahasa Indonesia, kelas X, Formula Fry.

\begin{abstract}
Readability relates to all elements in the text or reading material. Reading material in a textbook must always be considered because it affects the level of understanding of students. This study aims to find out the legibility of the text contained in the Indonesian Language Smart Textbook for SMA / MA Class X (Curriculum 2013) published by Erlangga, with a focus of research on non-literary discourse. There are five discourse samples that are calculated using the Formula Fry Graph. 2 of them have a discourse that matches the grade level of 5,6,7. 2 others have discourse that corresponds to grade level 7,8,9. And one sample that really has a discourse in accordance with the grade level 10, 11, 12 SMA / MA. From the results of the average sample calculation of the discourse, this book still has high readability for high school / MA level classes. So that a teaching role is needed to always examine teaching materials that are used, especially reading texts, to fit the grade level of students.
\end{abstract}

Keywords: legibility, Indonesian books, class X, Formula Fry 


\section{PENDAHULUAN}

Perkembangan ilmu pengetahuan di Indonesia semakin menunjukkan perbaikan. Hal tersebut dapat dilihat dari giatnya pemerintah Indonesia dalam menyusun dan mengembangkan program untuk meningkatkan mutu pendidikan, salah satunya dengan penyempurnaan kurikulum. Dalam perjalanan sejarah Indonesia sejak tahun 1945, kurikulum pendidikan nasional telah mengalami perubahan, yaitu pada tahun 1947 hingga terakhir pada tahun 2013.

Menurut Hidayat (2013) semua kurikulum nasional dikembangkan mengacu pada landasan yuridis Pancasila dan UUD 1945, perbedaan tiap kurikulum terletak pada penekanan pokok dari tujuan pendidikan dan pendekatan dalam mengimplementasian kurikulum tersebut. Disamping itu, Berdasarkan Undangundang Republik Indonesia No. 20 Tahun 2003 tentang Sistem Pendidikan Nasional disebutkan bahwa kurikulum sebagai seperangkat rencana dan pengaturan mengenai tujuan, isi, dan bahan pelajaran serta cara yang digunakan sebagai pedoman penyelenggaraan kegiatan pembelajaran untuk mencapai tujuan pendidikan tertentu.

Kurikulum dalam arti sempit merupakan kumpulan berbagai mata pelajaran yang diberikan peserta didik melalui kegiatan yang dinamakan proses pembelajaran (Kwartolo, 2002). Selanjutnya menurut Taba (dalam Munir, 2008) kurikulum adalah rencana untuk pembelajaran. Finch (1989) menambahkan kurikulum diartikan sebagai rangkaian atau susunan dari kegiatan pembelajaran dan pengalaman dari siswa dibawah naungan atau arahan dari sekolah. Dari beberapa pendapat tersebut, dapat ditarik simpulan bahwa kurikulum adalah seperangkat rencana yang berisi tujuan, isi, dan bahan pembelajaran serta cara yang digunakan sebagai pedoman penyelenggara kegiatan pembelajaran untuk mencapai tujuan.

Kurikulum 2013 adalah kurikulum berbasis kompetensi dan karakter secara terpadu yang merupakan penyempurnaan dari Kurikulum Tingkat Satuan Pendidikan (KTSP). Kurikulum ini dipandang sesuai dengan program pendidikan yang berbeda dengan kurikulum-kurikulum sebelumnya. Perbedaan tersebut nampak pada beberapa karakteristik Kurikulum 2013 yakni pendekatan saintifik dan penilaian otentik dalam pembelajaran. Kurikulum 2013 serentak diterapkan di semua jenjang pendidikan formal pada tahun ajaran 2014/2015 setelah dilakukan 
uji coba kurikulum di beberapa sekolah terpilih pada Juli 2013. Implementasi kurikulum mencakup tiga kegiatan pokok yakni pengembangan program, pelaksanaan pembelajaran, dan evaluasi (Riana Nurmalasari, dkk, 2016).

Disisi lain, berdasarkan Peraturan Pemerintah Nomor 19 Tahun 2005 tentang Standar Nasional Pendidikan sebagaimana telah beberapa kali diubah terakhir dengan Peraturan Pemerintah Nomor 13 Tahun 2015 tentang Perubahan Kedua Atas Peraturan Pemerintah Nomor 19 Tahun 2005 tentang Standar Nasional Pendidikan ditetapkan bahwa Standar Isi adalah kriteria mengenai ruang lingkup materi dan tingkat kompetensi untuk mencapai kompetensi lulusan pada jenjang dan jenis pendidikan tertentu. Ruang lingkup materi dirumuskan berdasarkan kriteria muatan wajib yang ditetapkan sesuai ketentuan peraturan perundang-undangan, konsep keilmuan, dan karakteristik satuan pendidikan dan program pendidikan. Selanjutnya, tingkat kompetensi dirumuskan berdasarkan kriteria tingkat perkembangan peserta didik, kualifikasi kompetensi Indonesia, dan penguasaan kompetensi yang berjenjang.

Berdasarkan Undang-Undang tersebut, pemilihan materi bacaan dalam proses pembelajaran merupakan komponen penting yang harus di perhatikan karena hal tersebut memengaruhi pemahaman peserta didik terhadap materi yang diajarkan. Bagaimanapun siswa merupakan pusat pembelajaran. Oleh sebab itu, guru harus selektif memilih bahan ajar berupa bacaan/wacana yang sesuai dengan jenjang pendidikan peserta didik sebagai upaya menyukseskan kemampuan peserta didik dalam memahami isi bacaan maupun dalam pembelajaran.

Menurut (Ketut Ngurah Yasa, 2013) dalam penelitiannya mengenai kecermatan formula keterbacaan dalam teks berbahasa Indonesia menyebutkan bahwa masalah keterbacaan dalam pengelolaan pengajaran membaca oleh sebagian besar guru bahasa Indonesia belum mendapat perhatian. Sebagian besar guru bahasa Indonesia tidak tahu alat ukur untuk menentukan tingkat keterbacaan teks. Ini berarti, sebagian besar guru bahasa Indonesia belum memiliki kemampuan untuk mengukur tingkat keterbacaan materi bacaan yang dijadikan sebagai bahan ajar. Akibatnya, dapat diduga ada kesenjangan antara materi bacaan yang disajikan dengan tingkat pemahaman pembaca. Kesenjangan ini kemungkinan dapat mengurangi minat dan motivasi membaca siswa. 
Dalam pengertiannya, keterbacaan adalah ukuran yang dilihat dari tingkat kesulitas atau kemudahan teks untuk dipahami siswa. keterbacaan sendiri merupakan bentuk dari evaluasi buku (Sulistyorini, 2006). Keterbacaan (readability) berhubungan dengan kemudahan teks untuk dibaca. Sebuah teks dapat dikatakan memiliki keterbacaan tinggi jika teks mudah untuk dipahami. Sedangkan teks dikatakan memiliki keterbacaan rendah jika teks sukar untuk dipahami (Andriana, 2012). Menurut Chen Jie (2012) ada beberapa faktor yang yang dapat menentukan tingkat keterbacaan suatu wacana, meliputi 1) Jumlah kalimat dalam wacana 2) Jumlah suku kata dalam wacana 3) Tata bahasa yang digunakan. Untuk mengetahui tingkat keterbacaan teks perlu diadakan pengukuran keterbacaan.

Seperti yang telah dijelaskan dalam pengertian keterbacaan di atas, keterbacaan berkaitan dengan keseluruhan unsur yang ada dalam teks atau materi bacaan. Menurut Gilliland (1972) ada lima cara untuk menentukan keterbacaan teks, yaitu penilaian subjektif para ahli, metode tanya jawab, formula keterbacaan, carta, dan tes cloze. Sehubungan dengan studi ini, maka yang dikaji menentukan keterbacaan teks adalah dengan formula keterbacaan. Formula-formula keterbacaan yang dimaksud merupakan rumus-rumus yang menghasilkan angka sebagai indeks keterbacaan (Nuttall, 1985; Sitepu, 2010). Dari beberapa formula keterbacaan yang ada, dalam penelitian ini penulis menggunakan formula keterbacaan dengan Formula Grafik Fry.

Chen Jie (2012) berpendapat bahwa Formula Grafik Fry merupakan pengukuran keterbacaan yang dianggap populer untuk mengukur keterbacaan. Menurut Sugeng (2016) Grafik Fry adalah hasil penelitian terhadap keterbacaan menggunakan bahasa inggris. Annisa menambahkan bahwa struktur kalimat yang terdapat dalam bahasa Idonesia berbeda jauh dengan bahasa inggris, terutama pada suku katanya. Oleh karena itu dalam penghitungan Grafik Fry perlu ditambah 1 langkah yaitu dengan cara mengalikan dengan 0,6 Harjasujana (dalam Annisa, 2016). Angka 0,6 ini diperoleh dari hasil perbandingan antara jumlah suku kata bahasa Inggris dengan bahasa Indonesia yaitu 6 banding 10 dengan artian 6 suku kata bahasa inggris kira-kira sama dengan 10 suku kata pada bahasa Indonesia (Sugeng, 2016). 
Menurut pendapat Sulistyorini (2006) Grafik Fry dianggap sebagai formula keterbacaan yang praktis serta mudah digunakan. Formula keterbacaan Grafik Fry diadaptasi oleh nama pembuatnya ialah Edward Fry yang dipublikasikan tahun 1977 pada majalah “Journal of Reading” Akhmad dan Yeti (dalam Sulistyorini, 2006). Nurlaili (2011) berpendapat bahwa tingkat keterbacaan pada Grafik Fry bersifat perkiraan, karenanya mungkin dapat terjadi penyimpangan pada bagian atas ataupun bawah $(-1$ atau +1$)$.

Berdasarkan penjelasan di atas, maka perlu dilakukan pengukuran tingkat keterbacaan teks menggunakan Keterbacaan Grafik Fry. Sampel yang digunakan untuk mengukur tingkat keterbacaan dalam penelitian ini adalah buku ajar Cerdas Berbahasa Indonesia untuk SMA/MA Kelas X (Kurikulum 2013) terbitan Erlangga, karena buku ajar tersebut dianggap merupakan salah satu buku yang menuntut siswa untuk dapat berperan aktif dalam proses pembelajaran. Tujuan diadakannya penelitian ini untuk mengetahui keterbacaan teks yang terdapat pada buku ajar bahasa Indonesia tersebut, terutama pada wacana non-sastra.

\section{METODE PENELITIAN}

Metode yang digunakan dalam penelitian ini adalah deskriptif kuantitatif yang berjenis penelitian pustaka. Dikatakan demikian sebab data diperoleh dari sumber yang bersifat kepustakaan, yaitu buku teks bahasa Indonesia yang berjudul Cerdas Berbahasa Indonesia untuk SMA/MA Kelas X (kurikulum 2013) terbitan Erlangga. Di dalam buku ini, terdapat delapan bab materi pembahasan. Meskipun demikian, penulis hanya menggambil lima 5 sampel wacana yang representatif dari bab-bab tertentu dalam buku tersebut, yaitu pada bab Laporan Observasi dan Teks Prosedur Kompleks.

\section{PEMBAHASAN}

Buku Cerdas Berbahasa Indonesia untuk SMA/MA Kelas X (kurikulum 2013) terbitan Erlangga memiliki delapan bab materi pembahasan. Dari setiap pembahasan tersebut terdapat wacana-wacana non-sastra dan beberapa wacana sastra.

Seperti yang telah dijelaskan pada bab pendahuluan di atas bahwa fokus penelitian ini adalah pada wacana non-sastra. Dari sekian banyak wacana non-sastra 
yang ada di buku tersebut, peneliti mengambil 5 sampel wacana yang representatif dari bab-bab tertentu dalam buku tersebut. Yaitu pada bab Laporan Observasi dan Teks Prosedur Kompleks.

Berikut merupakan lima sampel hasil pengukuran keterbacaan teks non-sastra menggunakan Formula Grafik Fry:

\section{Sampel 1:}

Berikut merupakan wacana yang terdapat pada bab tiga buku Cerdas Berbahasa Indonesia untuk SMA/MA Kelas $X$ tentang teks laporan observasi dengan judul “Plaza Banteng Kuto Besak, Tempat Wisata Baru Warga Palembang” (halaman 58):

Ada pemandangan baru di tepi Sungai Musi. Setiap sore, belasan orang terlihat nongkrong dengan santai di sebuah dermaga beton. Mereka umumnya memegang tangkai pancing, yang kailnya berulang kali terombang-ambing gelombang setiap kali ada ketek (perahu kayu bermesin tempel) melintas.

Anak-anak kecil dengan riang bermain air di undak-undakan yang ada di bawah dermaga. Meskipun air sungai berwarna cokelat itu berbau amis, mereka tampak sangat mengamatinya.

Suasana akan semakin ramai pada akhir pekan. Jika angin sedang kencang, tak sedikit anak muda yang datang ke dermaga itu untuk menaikkan layang-layang. Memancing, bermain air, bermain layangan, atau sekadar melewatkan senja dengan menikmati pemandangan di ...

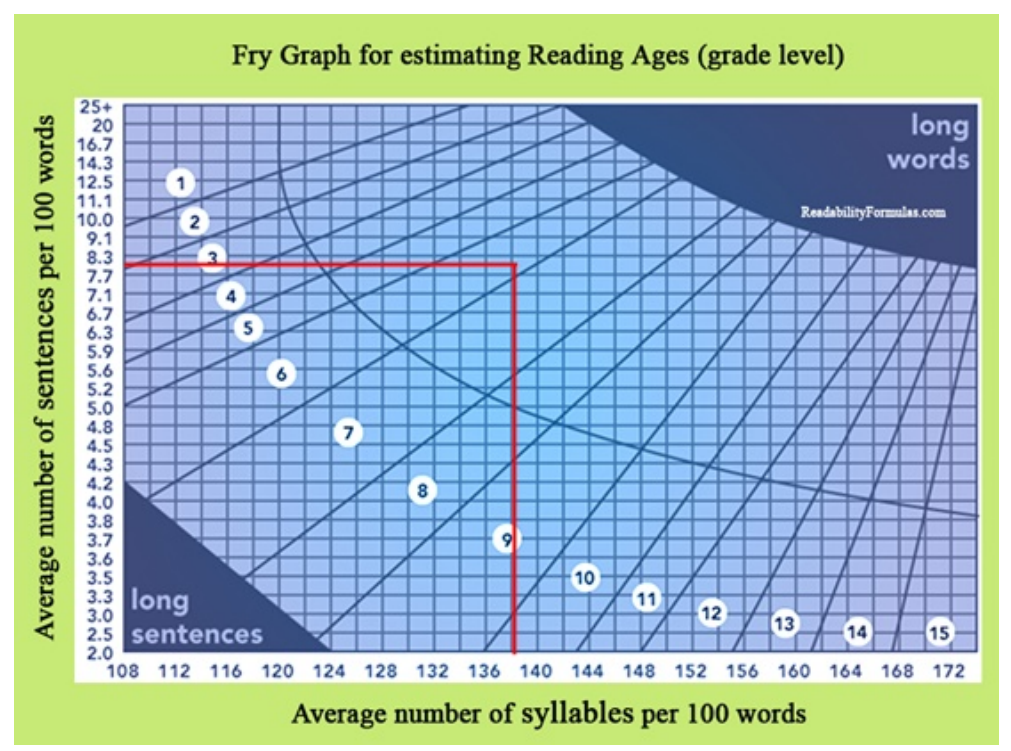

Gambar 1. Pengukuran tingkat keterbacaan Grafik Fry pada sampel wacana ke-1 
Gambar 1 merupakan hasil uji keterbacaan Grafik Fry menggunakan sampel paragraf pertama. Dengan hasil perhitungan 1) jumlah kalimat penuh dalam 100 kata : 7, 2) jumlah kalimat tidak penuh : 13/16 =0,8, 3) jumlah kalimat : $7+0,8=7,8$ yang diperoleh dengan cara menambahkan jumlah kalimat penuh dengan kalimat tidak penuh, selanjutnya, berdasarkan perhitungan suku kata diperoleh 4) jumlah suku kata : 228 x 0,6 = 136,8. Sehingga jika diinterpretasikan pada grafik Fry, wacana tersebut sesuai dengan tingkatan kelas 5, 6, 7 .

\section{Sampel 2:}

Berikut merupakan wacana yang terdapat pada bab lima buku Cerdas Berbahasa Indonesia untuk SMA/MA Kelas $X$ tentang teks prosedur kompleks dengan judul “Negosiasi Gaji tidak Mudah” (halaman 118):

Biasanya pada tahap akhir wawancara, si pencari kerja akan mendapat pertanyaan mengenai berapa besar gaji yang diinginkan. Kerap persoalan gaji memenag menjadi kendala bagi sebagian besar pencari kerja. Pada saat itulah, si pencari kerja biasanya sulit untuk menjawab besaran gaji yang ditawarkan perusahaan. Diterima atau tidak. Biasanya pencari kerja yang harus menyesuaikan sendiri dengan gaji yang diterimanya. Itu sebabnya negosiasi gaji menjadi bagian yang tersulit.

Jika menyebutkan angka yang terlalu tinggi, perusahaan mungkin akan mengurungkan niatnya untuk merekrut si pencari kerja tersebut. Sebaliknya, bila jumlah yang diminta terlalu rendah, pencari kerjalah yang akan bingung. Cara yang terbaik adalah mengetahui tingkat ...

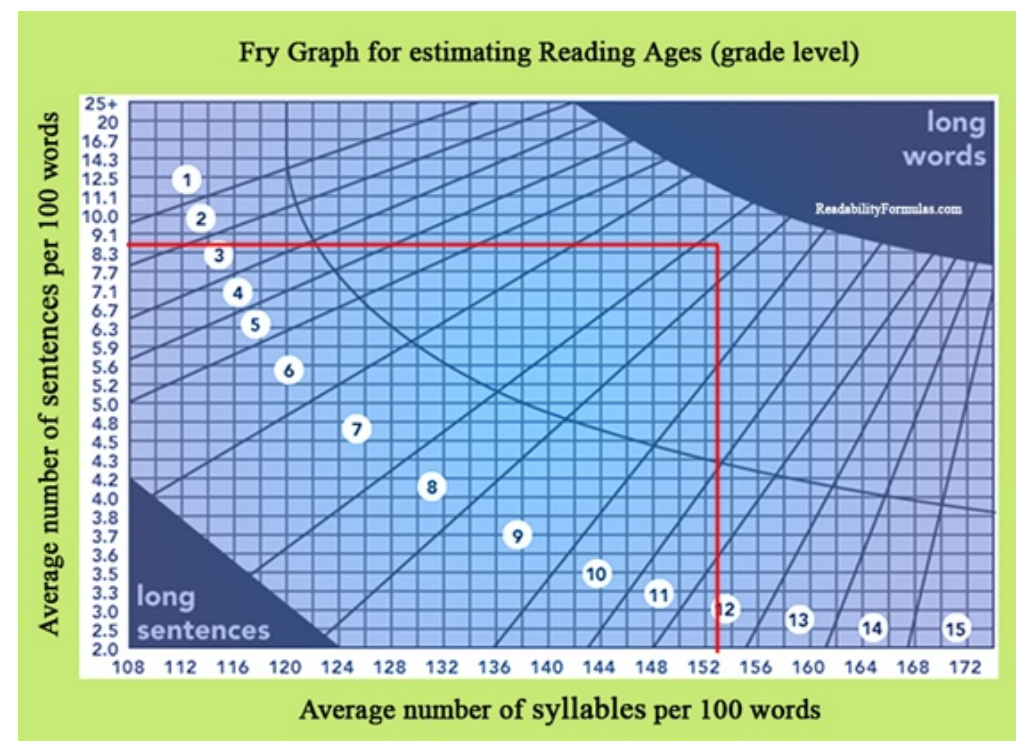


Gambar 2: Pengukuran tingkat keterbacaan Grafik Fry pada sampel wacana ke-2

Gambar 2 merupakan hasil uji keterbacaan Grafik Fry menggunakan sampel paragraf ke-2. Dengan hasil perhitungan 1) jumlah kalimat penuh dalam 100 kata : 8, 2) jumlah kalimat tidak penuh : 6/15 =0,4, 3) jumlah kalimat : $8+0,4=8,4$ yang diperoleh dengan cara menambahkan jumlah kalimat penuh dengan kalimat tidak penuh, selanjutnya, berdasarkan perhitungan suku kata diperoleh 4) jumlah suku kata : 255 x 0,6 = 153. Sehingga jika diinterpretasikan pada grafik Fry, wacana tersebut sesuai dengan tingkatan kelas 7, 8, 9.

\section{Sampel 3:}

Berikut merupakan wacana yang terdapat pada bab lima buku Cerdas Berbahasa Indonesia untuk SMA/MA Kelas $X$ tentang teks prosedur kompleks dengan judul “Tanaman itu Pasien” (halaman 121):

Lima tahun cukup lama menikmati suatu hasil usaha. Tapi, lima tahun akan terasa cepat jika digeluti dengan karya yang didasarkan hobi. Inilah kunci keberhasilan Warso Pawaka dalam mengembangkan bisnis duriannya.

Pria kelahiran Belitung yang mempersunting dara Priangan ini punya perhatian istimewa terhadap tanaman. Maklum, sejak kecil, ia sudah menyukai tanaman. Dari pergumulannya dengan tanaman itu, akhirnya lahir teori saling ketergantungan.

Tanaman itu makhluk hidup seperti manusia, butuh kasih sayang dan perawatan. Namun, kadang manusia itu egois. Maunya menikmati hasil dari tanaman, sedangkan tanamannya tak diperhatikan. Sikap seperti itu jelas tak akan membawa keberuntungan.

Dalam jiwa petani, harus tumbuh rasa kasih... 


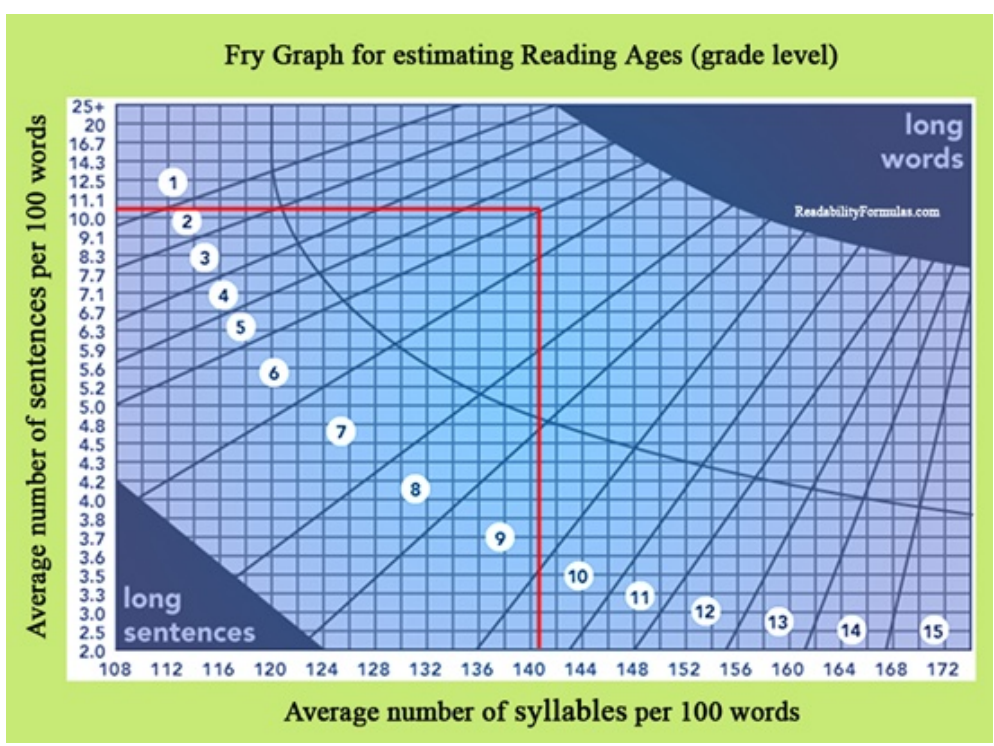

Gambar 3: Pengukuran tingkat keterbacaan Grafik Fry pada sampel wacana ke-3

Gambar 3 merupakan hasil uji keterbacaan Grafik Fry menggunakan sampel paragraf ke-3. Dengan hasil perhitungan 1) jumlah kalimat penuh dalam 100 kata : 10, 2) jumlah kalimat tidak penuh : 7/11 =0,6, 3) jumlah kalimat : $10+0,6=10,6$ yang diperoleh dengan cara menambahkan jumlah kalimat penuh dengan kalimat tidak penuh, selanjutnya, berdasarkan perhitungan suku kata diperoleh 4) jumlah suku kata : 236 x 0,6 = 141,6. Sehingga jika diinterpretasikan pada grafik Fry, wacana tersebut sesuai dengan tingkatan kelas 5,6,7, sama dengan tingkatan kelas pada sampel wacana pertama.

\section{Sampel 4:}

Berikut merupakan wacana yang terdapat pada bab enam buku Cerdas Berbahasa Indonesia untuk SMA/MA Kelas $X$ tentang teks prosedur kompleks dengan judul “Hak Kespro, Tidak Bisa Ditawar” (halaman 136):

Hak kesehatan reproduksi atau kespro untuk remaja mutlak harus kita upayakan agar bisa dinikmati semua remaja. Kita ingin agar semua remaja sehat secara jasmani, rohani, dan sosial.

Seperti yang kita tahu lewat berbagai media, saat ini kasus-kasus kesehatan reproduksi remaja yang terjadi sudah sampai tingkat mengkhawatirkan, baik bagi diri sendiri maupun pihak-pihak seperti orang tua, guru, dan masyarakat luas. 
Memang sih, kalau kita membicarakan kasus-kasus yang berkaitan dengan Kesehatan Reproduksi Remaja (KRR), bakal tidak ada habisnya. Coba kita perhatikan pemberitaan di media masa, baik cetak maupun elektronik, misalnya kasus kekerasan seksual atau pemerkosaan yang dialami teman-teman kita yang dilakukan orang-orang...

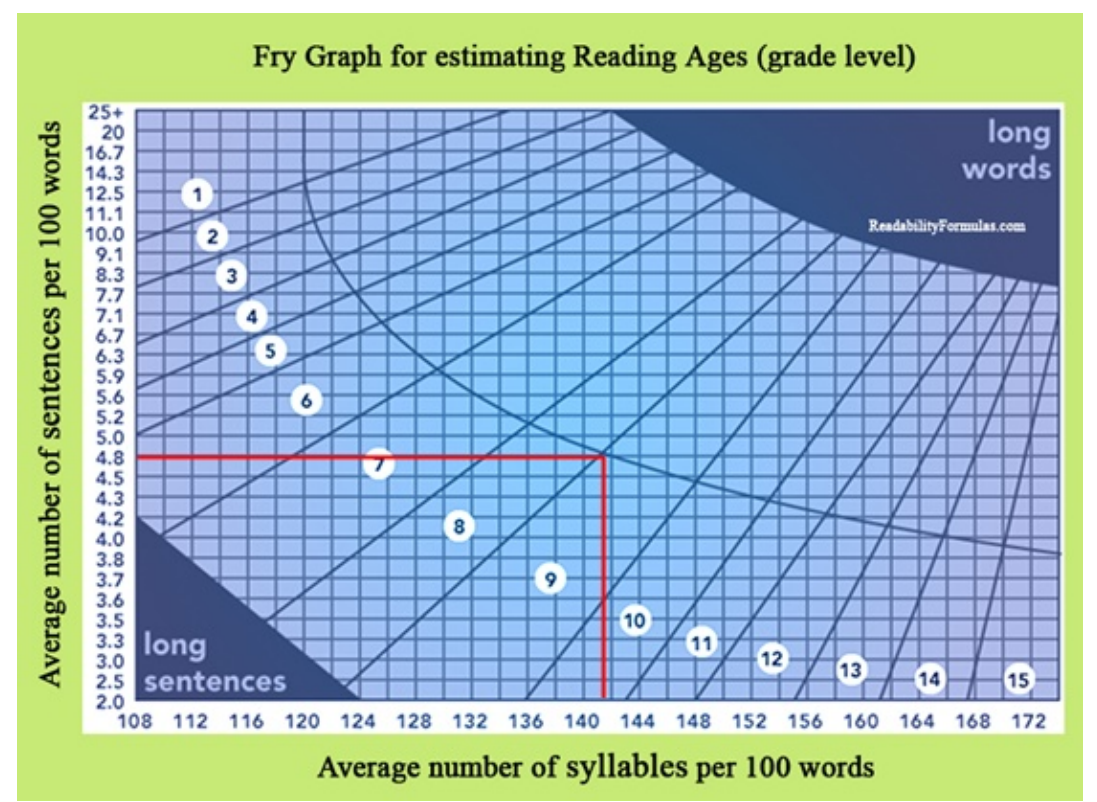

Gambar 4: Pengukuran tingkat keterbacaan Grafik Fry pada sampel wacana ke-4

Gambar 4 merupakan hasil uji keterbacaan Grafik Fry menggunakan sampel paragraf ke-4. Dengan hasil perhitungan 1) jumlah kalimat penuh dalam 100 kata : 4, 2) jumlah kalimat tidak penuh : 24/28 = 4,8,3) jumlah kalimat : $4+0,8=4,8$ yang diperoleh dengan cara menambahkan jumlah kalimat penuh dengan kalimat tidak penuh, selanjutnya, berdasarkan perhitungan suku kata diperoleh 4) jumlah suku kata : 239 x 0,6 = 143,4. Sehingga jika diinterpretasikan pada grafik Fry, wacana tersebut sesuai dengan tingkatan kelas 7,8,9, sama dengan tingkatan kelas pada sampel wacana kedua.

\section{Sampel 5:}

Berikut merupakan wacana yang terdapat pada bab enam buku Cerdas Berbahasa Indonesia untuk SMA/MA Kelas $X$ tentang teks prosedur kompleks dengan judul “Kembangkan Kompetensi dalam Meraih Pekerjaan” (halaman 148):

Tidak diragukan lagi tugas tersulit dari pemerintah adalah menciptakan lapangan pekerjaan baru bagi jutaan penduduk Indonesia. Roda perekonomian 
masih terus berjalan dengan angka pertumbuhan proyeksi empat persen. Pertanyaannya apakah angka sebesar itu, cukup untuk memberikan lapangan pekerjaan yang banyak. Tentu tidk, seperti dinyatakan oleh Menteri Koordinator Bidang Perekonomian, pertumbuhan ekonomi tersebut memang belum bisa menyerap semua tenaga kerja secara memadai. Oleh karena itu, Indonesia dituntut untuk bisa menyiapkan tenaga kerjanya untuk bersaing secara global.

Dengan melihat kondisi dunia kerja di Indonesia saat ini, memang sudah bukan saatnya lagi kita menggantungkan diri pada pemerintah. Apalagi masih banyak masalah yang masih harus...

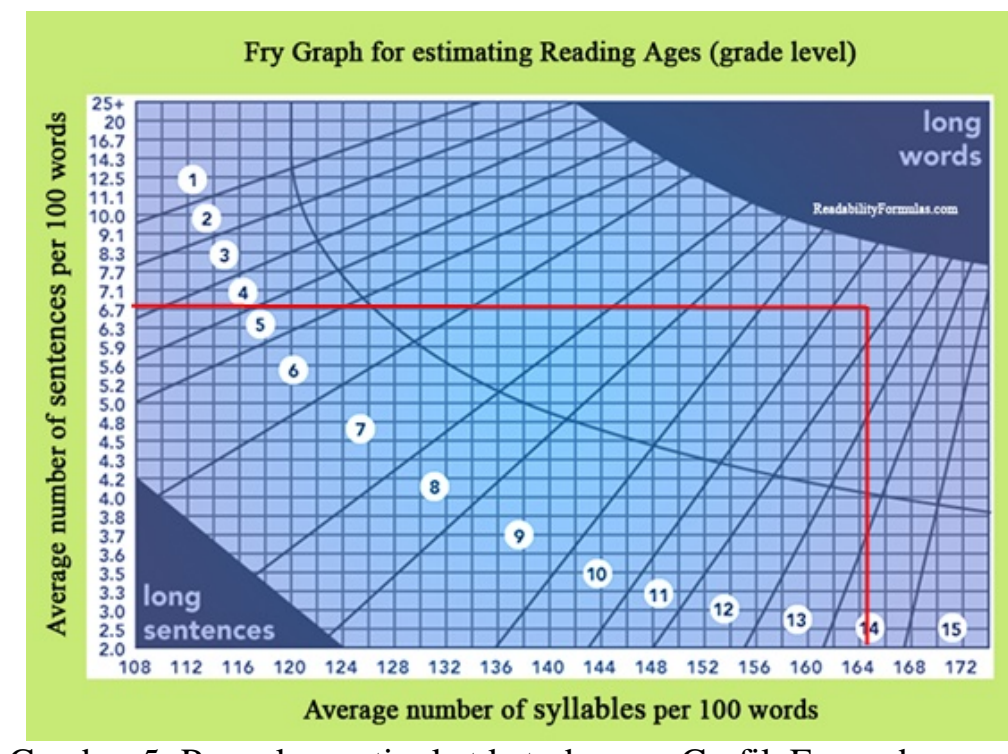

Gambar 5: Pengukuran tingkat keterbacaan Grafik Fry pada sampel wacana ke-5

Gambar 5 merupakan hasil uji keterbacaan Grafik Fry menggunakan sampel wacana ke-5. Dengan hasil perhitungan 1) jumlah kalimat penuh dalam 100 kata : 6, 2) jumlah kalimat tidak penuh : 7/9 =0,7,3) jumlah kalimat : $6+0,7=6,7$ yang diperoleh dengan cara menambahkan jumlah kalimat penuh dengan kalimat tidak penuh, selanjutnya, berdasarkan perhitungan suku kata diperoleh 4) jumlah suku kata : $274 \times 0,6=164,4$. Sehingga jika diinterpretasikan pada grafik Fry, wacana tersebut sesuai dengan tingkatan kelas 10,11,12.

Agar lebih mudah, berikut ini disajikan ringkasan perhitungan keterbacaan teks non-sastra pada buku Cerdas Berbahasa Indonesia untuk SMA/MA Kelas X (kurikulum 2013) dalam bentuk tabel: 


\begin{tabular}{|c|c|c|c|c|}
\hline \multirow{2}{*}{ Sampel } & \multirow{2}{*}{ Judul Teks } & \multicolumn{2}{|c|}{ Jumlah } & \multirow{2}{*}{$\begin{array}{c}\text { Tingkat } \\
\text { Kelas }\end{array}$} \\
\hline & & Kalimat & Suku Kata & \\
\hline 1 & $\begin{array}{lll}\text { Plaza Banteng } & \text { Kuto } & \text { Besak, } \\
\text { Tempat Wisata } & \text { Baru } & \text { Warga } \\
\text { Palembang } & & \\
\end{array}$ & 7,8 & 136,8 & $5,6,7$ \\
\hline 2 & Negosiasi Gaji tidak Mudah & 8,4 & 153 & $7,8,9$ \\
\hline 3 & Tanaman itu Pasien & 10,6 & 141,6 & $5,6,7$ \\
\hline 4 & Hak Kespro, Tidak Bisa Ditawar & 4,8 & 143,4 & $7,8,9$ \\
\hline 5 & $\begin{array}{l}\text { Kembangkan Kompetensi dalam } \\
\text { Meraih Pekerjaan }\end{array}$ & 6,7 & 164,4 & $10,11,12$ \\
\hline & Jumlah & 38,3 & 739,2 & \\
\hline & Rata-rata & 7,6 & 147,8 & $7,8,9$ \\
\hline
\end{tabular}

Jika dihitung berdasarkan rata-rata dari hasil uji kelima sampel tersebut, diperoleh:

1. Jumlah kalimat diperoleh dari jumlah keseluruhan kelima sampel : 38,3.

Kemudian dibagi dengan 5 sampel tersebut. Sehingga diperoleh : 7,6 kalimat.

2. Jumlah suku kata diperoleh dari jumlah keseluruhan kelima sampel : 739,2.

Kemudian dibagi dengan 5 sampel tersebut. Sehingga diperoleh : 147,8 suku kata.

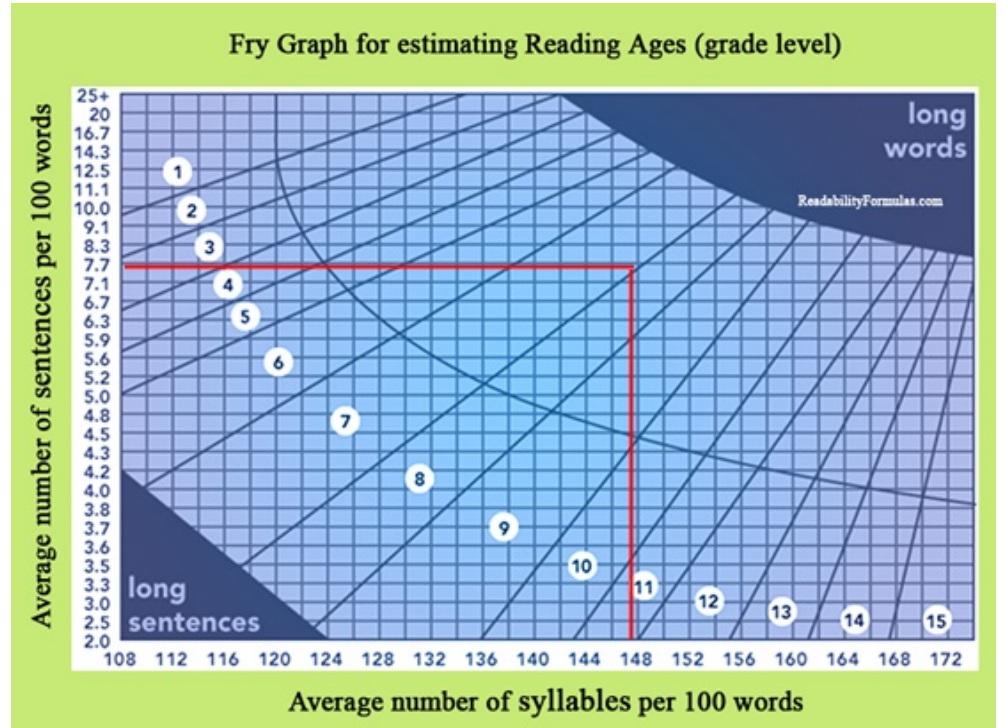

Gambar 6: Pengukuran tingkat keterbacaan Grafik Fry dari hasil rata-rata.

Jika diinterpretasikan pada grafik Fry, hasil dari rata-rata perhitungan sampel tersebut sesuai dengan tingkatan kelas 7,8,9 SMP/MTs.

Wacana yang dikatakan tinggi tingkat keterbacaannya, maka wacana tersebut semakin mudah untuk dipahami dan sebaliknya semakin rendah tingkat keterbacaan 
suatu wacana, maka semakin sulit wacana tersebut semakin sulit untuk dimengerti. Hal ini berarti bahwa suatu wacana yang rendah tingkat keterbacaan maka wacana tersebut tidak sesuai dengan disajikan pada jenjang yang menjadi sasaran (Harjasujana dan Yeti dalam Nuryani 2016).

\section{PENUTUP}

Berdasarkan hasil yang telah diperoleh, dapat ditarik simpulan bahwa keterbacaan teks pada buku ajar Cerdas Berbahasa Indonesia untuk SMA/MA Kelas X (kurikulum 2013) terbitan Erlangga memiliki tingkat keterbacaan yang tinggi, sehingga tidak sesuai dengan tingkatan kelas X SMA. Jika dilihat dari hasil ratarata perhitungan pada pembahasan diatas, wacana non-sastra pada buku ajar Cerdas Berbahasa Indonesia untuk SMA/MA Kelas X (kurikulum 2013) terbitan Erlangga lebih sesuai dengan tingkatan kelas 8 SMP/MTs.

\section{DAFTAR RUJUKAN}

Fatin, Idhoofiyatul. 2017. Keterbacaan Buku Teks Bahasa Indonesia Kelas X Kurikulum 2013 Edisi Revisi 2016 dengan Formula Fry. Jurnal Belajar Bahasa Universitas Muhammadiyah Jember. http://jurnal.unmuhjember.ac.id/index.php/BB/article/view/643.

Himala , Sidra Pawahyuning Trihanis, dkk. 2016. Keterbacaan Teks Buku Ajar Berbasis Aktivitas pada Materi Ruang Lingkup Biologi Kelas X SMA. http://jurnalmahasiswa.unesa.ac.id/article/23469/34/article.pdf.

Isabela, Siti Natasya. Analisis Keterbacaan Wacana Buku Sekolah Elektronik Bahasa Indonesia Jenjang SMP.

Kaldum, Muhammad Ibnu. 2016. Tingkat Keterbacaan Wacana Nonfiksi pada Buku Teks Bahasa Indonesia Pegangan Siswa SMA Kelas X Kurikulum 2013 dengan Menggunakan Metode Grafik Fry. Http://ojs.uho.ac.id/index.php/HUMANIKA/article/view/759/PDF.

Nurmalasari, Riana, dkk. 2016. Peran Guru dalam Implementasi Kurikulum 2013. Http://ap.fip.um.ac.id/wp-content/uploads/2016/03/55-Riana-Nurmalasari-RetaDian-Purnama-Wati-Poppy-Puspitasari.pdf.

Nurmalasari, Riana, dkk. Peran Guru dalam Implementasi Kurikulum 2013. Universitas Negeri Malang.

Yasa , Ketut Ngurah. 2013. Kecermatan Formula Keterbacaan sebagai Penentu Keefektifan Teks. 